\title{
Lvads: A Two-Sided Dilemma when Buying Time for Heart Transplantation
}

\author{
Binks $\mathbf{M}^{1,2}$ \\ ${ }^{1}$ Wagga Wagga Rural Referral Hospital, NSW, Australia. \\ ${ }^{2}$ Faculty of Medicine, University of New South Wales, NSW, Australia
}

Received: 11 January, 2017; Accepted: 23 February, 2017; Published: 04 March, 2017

*Corresponding author: Matthew Binks, Wagga Wagga Rural Referral Hospital, Wagga Wagga, NSW, Australia, E-mail: m.binks@unsw.edu.au

\begin{abstract}
Our ageing population is experiencing an unprecedented level of heart disease. Medical therapy is often inadequate in those with endstage heart failure. Mechanical cardiac support devices are becoming increasingly utilized as a means of both bridging these patients to heart transplant and as destination therapy. However, they are far from risk-free. This review encompasses the complications associated with left ventricular assist devices (LVADs), including their often-unpredictable effects on the right ventricle.
\end{abstract}

\section{Review}

Lifetime risk of heart failure is approximately $20 \%$ and the one-year mortality rate of end-stage heart failure is in excess of $50 \%[1,2]$. Heart transplantation is the gold standard therapy for end-stage heart failure. Despite improvements, heart donation rates in Australia remain inadequate [3] and prior to the advent of mechanical circulatory support up to $20 \%$ of patients on the waiting list died [2-5].

By alleviating left ventricular (LV) strain in a failing heart, left ventricular assist devices (LVADs) are used to buy time for patients on the heart transplant waiting list and are now the destination therapy for patients denied transplant [2,5]. Patients are chosen for LVAD based on criteria that indicate cardiac and organ status, for example pulmonary capillary wedge pressure and cardiac index [6]. The updated scale for classifying heart failure and the need for mechanical circulatory support, the Interagency Registry for Mechanically Assisted Circulatory Support (INTERMACS) determines suitability for LVAD [6]. Continuous-flow LVADs, which involve a single moving part, the propeller, are being used in increasing numbers, largely supplanting pulsatile devices. These draw and propel blood continuously, delivering it from the apex of the LV, or other inflow sites such as the left atrial appendage, via an inflow cannula to the aortic root through an outflow graft. By stabilizing haemodynamics and ameliorating end organ dysfunction, LVADs bridge patients to transplant with up to $90 \%$ survival $[4,7,8]$. Whilst patients treated solely by medical interventions are left greatly debilitated, most LVAD patients return to daily activities - and even exercise - with reduced readmission to hospital [5, 9].
Right ventricular failure (RVF) is a leading cause of LVAD failure. Estimates of incidence of RVF following LVAD implantation vary from 5\% [10] to 35\% [11]. Perioperative and overall mortalities are increased by approximately $19-44 \%$ and $20-23 \%$ respectively in LVAD patients with RVF $[4,11,12]$. LVAD patients are considered to have refractory RVF when requiring more than 14 days of intravenous inotropic support, over 48 hours of inhaled nitric oxide support or right ventricular (RV) mechanical assistance after LVAD insertion $[4,10]$. Mechanical assistance is required when a patient is unable to be weaned from cardiopulmonary bypass $[4,12,13]$. The right ventricular assist device (RVAD) is the most common device used for mechanical assistance of the RV. Patients fare better with expedited RVAD insertion and hence multiple attempts have been made to predict $\mathrm{RV}$ deterioration in patients receiving a $\operatorname{LVAD}[4,8,12,14,15]$.

Complicating the matter of RVF is the unpredictable return of RV function days and weeks after a LVAD relieves RV afterload [8,14,16-18]. Because a LVAD relieves pulmonary capillary wedge pressure, a structurally normal RV may regain function following temporary mechanical support $[8,17,18]$. Hence temporary RVAD placement has recently gained popularity [1921]. Once the RVAD is removed patient survival to transplant returns to levels experienced with isolated LVAD implantation $[22,23]$. Alternatively, short-term use of veno-pulmonary arterial extra-corporeal membrane oxygenation (VPA-ECMO) can be implemented [17]. VPA-ECMO has the advantage of extracorporeal membrane oxygenation. This ensures complete oxygenation of the patient's blood, which potentially benefits the ailing myocardium, particularly in hypoxic patients[24]. For this reason, in a study by Bhama et al., 2009, six of 35 patients requiring RVAD required intraoperative exchange of RVAD for veno-arterial ECMO [19].

Multiple other factors must be considered before and after LVAD insertion. The balance between bleeding and thrombosis in LVAD recipients is of utmost importance. The operative inflammatory milieu, coupled with the presence of aforeign body and altered haemodynamics makes atrial, ventricular and pump thrombosis a high risk with potentially catastrophic consequences [25,26]. Thromboembolism affects under $5 \%$ 
of LVAD patients with modern pumps [25,27]. Previous acute myocardial infarction, cannulation of the left atrial appendage and postoperative bleeding all increase the likelihood of thrombosis with LVAD therapy [25]. Continuous-flow LVADs appear to be of similar risk to pulsatile LVADs, even with variable adherence to INR targets [27]. A combination of prophylactic aspirin therapy (with or without an additional antiplatelet) and warfarinisation to an INR of 2-3 (or even 1.5-2.5) is reasonably employed in continuous-flow devices, but is dependent on the LVAD manufacturer $[2,26,28,29]$. Thromboembolic prophylaxis increases the risk of bleeding [28]. Approximately $10 \%$ of patients with continuous-flow LVADs develop gastrointestinal (GI) bleeding requiring blood transfusions [30]. Others have reported much higher rates of GI bleeding - up to $40 \%$ - much higher than pulsatile devices [28,31]. A past history of GI bleeding, particularly if recent, must be carefully considered before LVAD implantation [30]. Bleeding is not only troubling in the short term but the potential need to withhold blood thinners increases the subsequent likelihood of thrombo embolism [28].

LVAD recipients are susceptible both to infections unrelated to the device (urinary tract infection, pneumonia etc) and those complicating the various foreign bodies used in the therapy. In a review of 247 LVAD recipients at their institution, Nienaber et al found infection of the percutaneous driveline to be the most common LVAD-related infection and the most common cause of septicaemia in these patients [32]. Owing to the high prevalence of bacterial colonization, diagnosis of driveline infections can be difficult andimaging with ultrasound or CT is often vital for identifying and defining any associated abscess. Infections should be treated aggressively so as to prevent blood stream infection [32-34]. If a diagnosis of blood stream infection is made, it may involve the LVAD and this must be determined early. Intraoperative device cultures are the gold standard for this purpose but TOE is more commonly employed as a firstline measure [33]. Clinical suspicion is raised if a blood stream infection fails to respond to appropriate antibiotics. Whilst replacement of infected LVADs is optimal, it is performed at great risk and only if lifelong antimicrobial suppression has failed $[29,32,33]$.

LVADs are an exciting addition to the armamentarium forcombating heart failure. However, once used, it is far from an easy patient journey. Consequently, LVAD technology and the understanding and prediction of LVAD complications, such as RVF, must continue to improve.

\section{References}

1. Roger VL. The Heart Failure Epidemic. Int J Environ Res Public Health. 2010;7(4):1807-1830.

2. Rose EA, Gelijns AC, Moskowitz AJ, Heitjan DF, Stevenson LW Dembitsky W, et al. Long-Term use of a left ventricular assist device for end-stage heart failure. N Engl J Med. 2001; 345(20):1435-1443.

3. Registry, A., 2016 Annual Report, Chapter 7: Heart Donation. 2016, Australia and New Zealand Dialysis and Transplant Registry, Adelaide, Australia.
4. Kormos RL, Teuteberg JJ, Pagani FD, Russell SD, John R, Miller LW, et al. Right ventricular failure in patients with the HeartMate II continuousflow left ventricular assist device: incidence, risk factors, and effect on outcomes. J Thorac Cardiovasc Surg. 2010;139(5):1316-1324. doi: 10.1016/j.jtcvs.2009.11.020

5. Slaughter MS, Rogers JG, Milano CA, Russell SD, Conte JV, Feldman $D$ et al. Advanced Heart Failure Treated with Continuous-Flow Left Ventricular Assist Device. N Engl J Med. 2009;361(23):2241-2251. doi: 10.1056/NEJMoa0909938.

6. Stevenson LW, Pagani FD, Young JB, Jessup M, Miller L, Kormos RL et al. INTERMACS Profiles of Advanced Heart Failure: The Current Picture. J Heart Lung Transplant. 2009;28(6):535-41. doi: 10.1016/j. healun.2009.02.015.

7. Craig, M.L., Treatment of RHF in the era of LVAD. Current Heart Failure Report, 2011. 8: p.

8. Fitzpatrick JR, Frederick JR, Hiesinger W, Hsu VM, McCormick RC, Kozin ED, et al. Early planned institution of biventricular mechanical circulatory support results in improved outcomes compared with delayed conversion of a left ventricular assist device to a biventricular assist device. J Thorac Cardiovasc Surg. 2009;137(4):971-977. doi: 10.1016/j.jtcvs.2008.09.021

9. Garbade J, Bittner HB, Barten MJ, Mohr FW. Current Trends in Implantable Left Ventricular Assist Devices. Cardiol Res Pract. 2011;2011:290561. doi: 10.4061/2011/290561

10. Lee S, Kamdar F, Madlon-Kay R, Boyle A, Colvin-Adams M, Pritzker $M$, et al., Effects of the HeartMate II continuous-flow left ventricular assist device on right ventricular function. J Heart Lung Transplant. 2010;29(2):209-215. doi: 10.1016/j.healun.2009.11.599

11. Matthews JC, Koelling TM, Pagani FD, Aaronson KD. The right ventricular failure risk score: a pre-operative tool for assessing the risk of right ventricular failure in left ventricular assist device candidates. J Am Coll Cardiol. 2008 Jun 3;51(22):2163-2172. doi: 10.1016/j.jacc.2008.03.009

12. Marzec LN, Ambardekar AV. Preoperative Evaluation and Perioperative Management of Right Ventricular Failure After Left Ventricular Assist Device Implantation. Semin Cardiothorac Vasc Anesth. 2013 Dec;17(4):249-261. doi: 10.1177/1089253213488246

13. Ochiai Y, McCarthy PM, Smedira NG, Banbury MK, Navia JL, Feng J, et al. Predictors of severe right ventricular failure after implantable left ventricular assist device insertion: analysis of 245 patients. Circulation. 2002;106(12 Suppl 1):I198-202

14. Fitzpatrick III JR, Frederick JR, Hsu VM, Kozin ED, O’Hara ML, Howell E, et al., Risk score derived from pre-operative data analysis predicts the need for biventricular mechanical circulatory support. J Heart Lung Transplant. 2008;27(12):1286-1292. doi: 10.1016/j. healun.2008.09.006

15. Singh G. Treatment Options for End-Stage Cardiac Failure. ECMO. 2014:217-235. doi: 10.1007/978-88-470-5427-1_19

16. Deng MC, Edwards LB, Hertz MI, Rowe AW, Keck BM, Kormos R, et al. Mechanical circulatory support device database of the International Society for Heart and Lung Transplantation: Third annual report-2005. J Heart Lung Transplant. 2005;24(9):1182-1187.

17. Gupta S, Woldendorp K, Muthiah K, Robson D, Prichard R, Macdonald PS, et al. Normalisation of haemodynamics in patients with endstage heart failure with continuous-flow left ventricular assist device therapy. Heart Lung Circ. 2014 Oct;23(10):963-9. doi: 10.1016/j. hlc.2014.04.259 
18. Patil NP, Mohite PN, Sabashnikov A, Dhar D, Weymann A, Zeriouh $\mathrm{M}$, et al. Preoperative predictors and outcomes of right ventricular assist device implantation after continuous-flow left ventricular assist device implantation. J Thorac Cardiovasc Surg. 2015;150(6):1651-8. doi: 10.1016/j.jtcvs.2015.07.090

19. Bhama JK, Kormos RL, Toyoda Y, Teuteberg JJ, McCurry KR, Siegenthaler MP. Clinical Experience Using the Levitronix CentriMag System for Temporary Right Ventricular Mechanical Circulatory Support. J Heart Lung Transplant. 2009;28(9):971-976. doi: 10.1016/j. healun.2009.04.015

20. Chen JM, Levin HR, Rose EA, Addonizio LJ, Landry DW, Sistino JJ, et al. Experience with right ventricular assist devices for perioperative right-sided circulatory failure. Ann Thorac Surg. 1996;61(1):305-310

21. Küçüker SA, Stetson SJ, Becker KA, Akgül A, Loebe M, Lafuente JA, et al. Evidence of improved right ventricular structure after LVAD support in patients with end-stage cardiomyopathy. J Heart Lung Transplant. 2004;23(1):28-35.

22. Cohn WE, Gregoric ID, La Francesca S, Frazier OH. Bedside Right Ventricular Assist Device Removal in the Conscious Patient. Ann Thorac Surg. 2007;83(4):1556-1557.

23. Loforte A, Montalto A, Lilla Della Monica P, Musumeci F. Simultaneous temporary Centri Mag right ventricular assist device placement in HeartMate II left ventricular assist system recipients at high risk of right ventricular failure. Interact Cardiovasc Thorac Surg. 2010;10(6):847-850. doi: 10.1510/icvts.2009.230706

24. Scherer M, Sirat AS, Moritz A, Martens S. Extracorporeal membrane oxygenation as perioperative right ventricular support in patients with biventricular failure undergoing left ventricular assist device implantation. Eur J Cardiothorac Surg. 2011;39(6):939-944. doi: 10.1016/j.ejcts.2010.09.044

25. Reilly MP, Wiegers SE, Cucchiara AJ, O’Hara ML, Plappert TJ, Loh E, et al. Frequency, risk factors, and clinical outcomes of left ventricular assist device-associated ventricular thrombus. Am J Cardiol. 2000;86(10):1156-1159

26. Boyle AJ, Russell SD, Teuteberg JJ, Slaughter MS, Moazami N, Pagani FD, et al. Low thromboembolism and pump thrombosis with the
HeartMate II left ventricular assist device: analysis of outpatient anti-coagulation. J Heart Lung Transplant. 2009;28(9):881-887. doi: 10.1016/j.healun.2009.05.018

27. John R, Kamdar F, Liao K, Colvin-Adams M, Miller L, Joyce L, et al. Low thromboembolic risk for patients with the Heartmate II left ventricular assist device. J Thorac Cardiovasc Surg. 2008;136(5):1318-23. doi: 10.1016/j.jtcvs.2007.12.077

28. Stern DR, Kazam J, Edwards P, Maybaum S, Bello RA, D’Alessandro $\mathrm{DA}$, et al. Increased incidence of gastrointestinal bleeding following implantation of the HeartMate II LVAD. J Card Surg. 2010;25(3):352356. doi: 10.1111/j.1540-8191.2010.01025.x

29. Sabashnikov A, Mohite PN, Weymann A, Patil NP, Hedger M, Sáez DG, et al. Outcomes after implantation of 139 full-support continuousflow left ventricular assist devices as a bridge to transplantation. Eur J Cardiothorac Surg. 2014;46(5):e59-66. doi: 10.1093/ejcts/ezu325

30. Slaughter MS, Pagani FD, Rogers JG, Miller LW, Sun B, Russell SD, et al. Clinical management of continuous-flow left ventricular assist devices in advanced heart failure. J Heart Lung Transplant. 2010;29(4 Suppl):S1-39. doi: 10.1016/j.healun.2010.01.011

31. Crow S, John R, Boyle A, Shumway S, Liao K, Colvin-Adams M, et al. Gastrointestinal bleeding rates in recipients of nonpulsatile and pulsatile left ventricular assist devices. J Thorac Cardiovasc Surg. 2009;137(1):208-215. doi: 10.1016/j.jtcvs.2008.07.032

32. Nienaber JJ, Kusne S, Riaz T, Walker RC, Baddour LM, Wright AJ, et al. Clinical Manifestations and Management of Left Ventricular Assist Device-Associated Infections. Clin Infect Dis. 2013;57(10):14381448. doi: $10.1093 / \mathrm{cid} / \mathrm{cit} 536$

33. Stulak JM, Maltais S, Cowger J, Joyce LD, Daly RC, Park SJ, et al., Prevention of percutaneous driveline infection after left ventricular assist device implantation: prophylactic antibiotics are not necessary. ASAIO J. 2013;59(6):570-574. doi: 10.1097/MAT.0b013e3182a9e2a5

34. Cabrera AG, Khan MS, Morales DL, Chen DW, Moffett BS, Price JF, et al. Infectious complications and outcomes in children supported with left ventricular assist devices. J Heart Lung Transplant. 2013;32(5):51824. doi: $10.1016 /$ j.healun.2013.02.002 